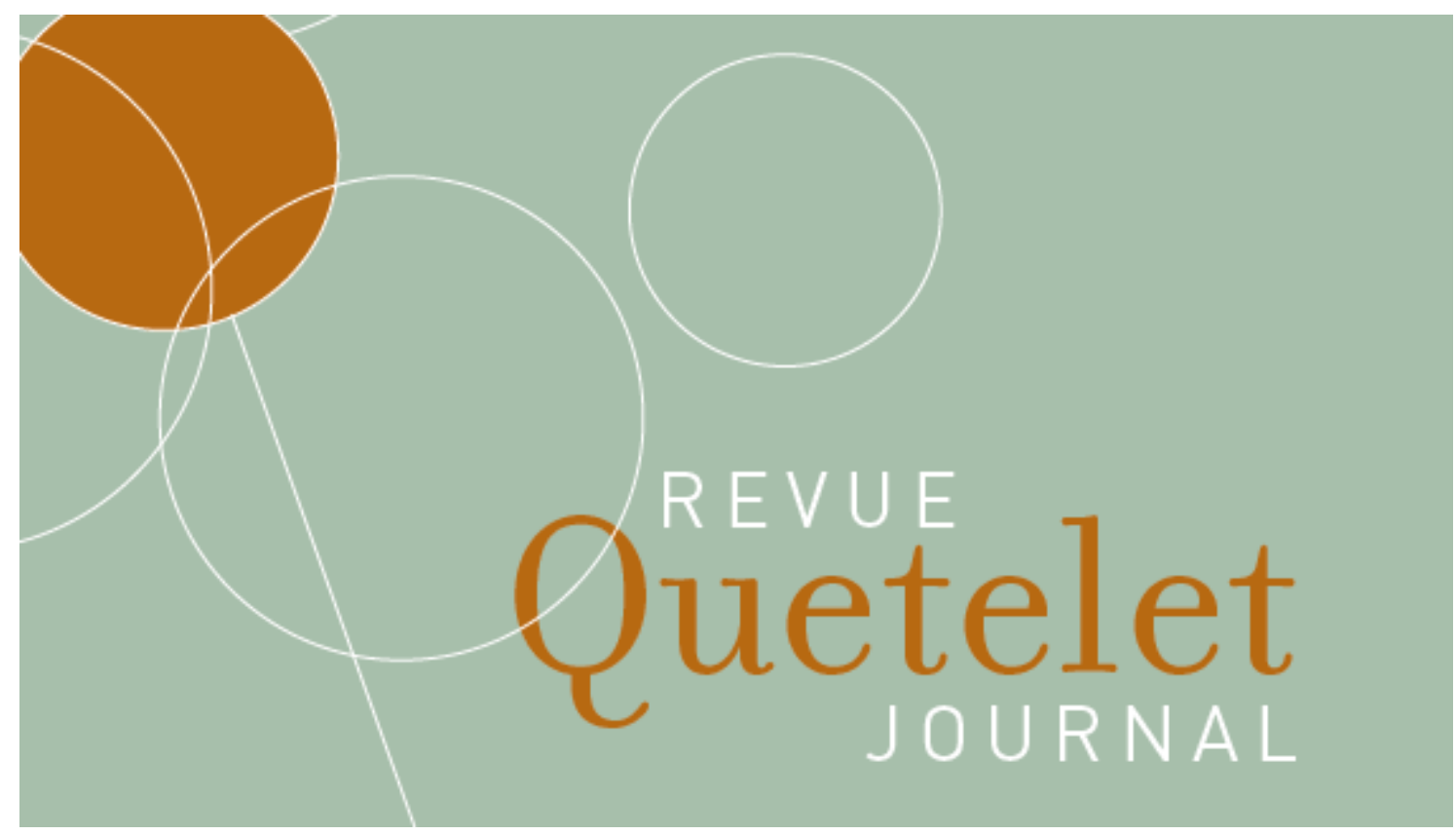

Vol. 7, n 1, avril 2019, pp. 7-26

DOI : 10.14428/rqj2019.07.01.01

ISSN: $2593-9157$

"No money, no honey»?

Poverty and young men's unmarried relationships in urban Burkina Faso

\author{
Anne E. Calvès
}

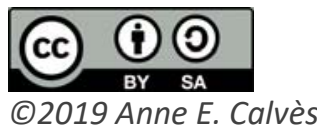

This work is licensed under a Creative Commons Attribution-NonCommercial 4.0 International License. You can share, adapt the material for non-commercial purposes provided that you give appropriate credit and indicate if changes were made. For details see https://creativecommons.org/licenses/by-sa/4.0/

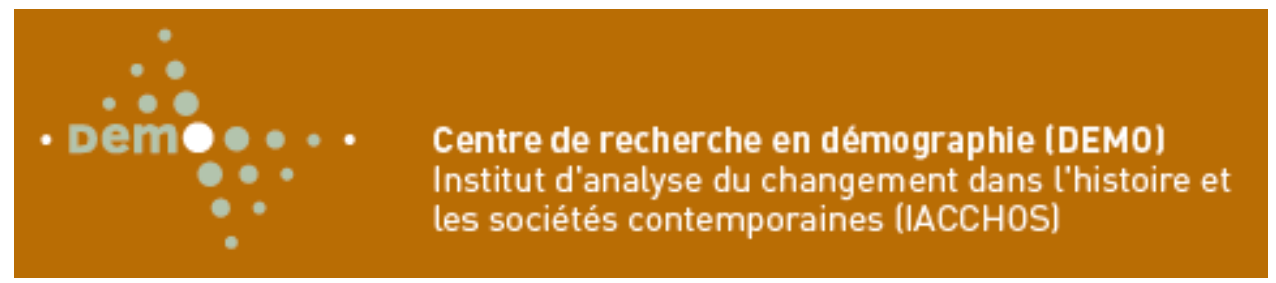





\title{
"No money, no honey»? Poverty and young men's unmarried relationships in urban Burkina Faso
}

\author{
ANne E. CALVÈs ${ }^{1}$
}

\begin{abstract}
Résumé
Au Burkina Faso, le fait qu'un jeune homme célibataire subvienne aux besoins de sa petite amie est un impératif fortement ancré dans les normes de genre. Avec des taux de chômage élevés chez les jeunes et une importance grandissante de l'aspect matériel des relations intimes, cette obligation financière semble pourtant de plus en plus difficile à respecter. Des études qualitatives dans les villes d'Afrique de l'Ouest ont d'ailleurs rapporté la frustration de jeunes chômeurs et de jeunes défavorisés qui se plaignent de leur incapacité à attirer les filles et avoir des copines à cause de leur situation financière. L'objectif de l'étude est d'explorer quantitativement cette "marginalisation sexuelle» des jeunes citadins les plus pauvres, observée par les anthropologues. Sur la base d'une enquête biographique réalisée auprès de jeunes adultes en 2010 à Ouagadougou au Burkina Faso, l'analyse s'intéresse à l'impact du statut socio-économique des jeunes hommes célibataires sur leurs histoires relationnelles. Les résultats montrent que l'hypothèse d'une marginalisation sexuelle des jeunes hommes défavorisés est fondée. Toute chose égale par ailleurs, les jeunes chômeurs et les jeunes hommes qui sont peu ou pas scolarisés ont, au fil du temps, des chances significativement plus faibles que leurs homologues plus nantis d'être dans des relations stables.
\end{abstract}

Mots-clés

Afrique, Burkina Faso, jeunes, masculinité, relations sexuelles, pauvreté, conditional gap time Cox models.

\section{Abstract}

In Burkina Faso, the expectation that a young man has to financially support his girlfriend is deeply rooted in gender norms and is a keystone of masculinity construction. With the persistent economic crisis, high unemployment rates, and the growing importance of materiality in intimate relationships, this economic obligation seems more and more difficult to fulfill, however. Qualitative studies have reported the frustration of unemployed and poorer young men in West African

1. Sociology Department, Université de Montréal. 
cities who face difficulties in attracting girlfriends due to their economic condition. This sexual marginalization of poorer city-dwellers, suggested by anthropological evidence, has yet to be explored quantitatively. This is the purpose of the study. Based on unique life history data collected from young adults in 2010 in the capital city of Ouagadougou, the present research examines the impact of poverty on young men's sexual relationship histories. Although they engage in a number of premarital relationships, results suggest that young men in Ouagadougou are not equal in the search for sexual partners. The study provides support for the "sexual marginalization hypothesis» and shows that, other things being equal, unemployed males and uneducated young men are significantly less likely than their better-off counterparts to engage in relationships over time

\section{Keywords}

Africa, Burkina Faso, youth, masculinity, sexual relations, poverty, conditional gap time Cox models.

\section{Introduction}

In Burkina Faso, although marriage remains almost universal, it often no longer represents the beginning of exposure to sexual activity, especially in urban areas. Like in other African cities, unmarried youths in contemporary Ouagadougou often engage in a number of premarital sexual relationships, either sequentially or simultaneously, for various reasons (Mazzocchetti, 2010; Rossier et al., 2013; Sawadogo, 2016). If some of these relationships, such as those with older, wealthier, married men, seem explicitly financially driven, the line between the affective and the material dimensions of most male-female intimate relationships in African cities is often blurred (Poulin, 2007; Cole, 2009; Hunter, 2010). In fact, like in many other parts of the world, «romance and finance are in mutual embrace» in the African context (Mills, Sewakiryanga, 2005, p. 94) and money and gift exchanges are an essential component of the courting process that is intrinsically linked to masculine and feminine identities. In Burkina Faso, for instance, the expectation that an unmarried man has to financially support his girlfriend is strong and deeply rooted in gender norms and in the social representation of men as economic providers (Lallemand, 1977; Mazzocchetti, 2010).

Yet, with the persistent economic crisis and youth unemployment that have characterized most sub-Saharan African cities, including Ouagadougou (Calvès, Kobiané, 2014), since the beginning of the 1990s, this tacit financial obligation seems more and more difficult to fulfill for several young urban males. In fact, anthropological evidence suggests that 
deteriorating economic conditions have actually exacerbated moneyrelated conflicts and tensions between male and female youths (Meekers, Calvès, 1997; Mills, Sewakiryanga, 2005; Cole, 2009; Hunter, 2010; Mains, 2012). While young women accuse men of being unreliable, young men complain about the materialism of their female counterparts. Underlying these critiques against women is the growing sense among a number of young men in African cities that economic hardship restrains their sexual options. In a context where masculinity construction is strongly linked to sexuality and young men's ability to have girlfriends and multiple sexual partners (Brown et al., 2005), several studies have actually reported the bitterness and frustration expressed by unemployed, poorer urban men who feel marginalized on the dating scene and fear prolonged sexual abstinence or difficulties in keeping their girlfriends due to their economic condition (Mills, Sewakiryanga, 2005; Mazzocchetti, 2010; Mains, 2012).

While some quantitative studies have documented the difficult transition to marriage among a young generation of unemployed males and informal sector workers (Antoine, 2006; Calvès, 2007; Bocquier, Khasakhala, 2009), the marginalization of poorer urban men on the dating scene suggested by the anthropological evidence has yet to be explored quantitatively. Based on a unique retrospective life calendar history survey conducted among young adults in 2010 in Ouagadougou, the purpose of the study is to contribute to fill this research gap and to examine the impact of young male poverty on sexual relationship history. More specifically, the study analyzes the effect of unmarried young males' socioeconomic backgrounds, occupations and levels of educational attainment on their ability to engage in stable sexual relationships over time.

\section{Youth employment crisis, failed masculinity and gender tensions in urban Africa}

In Burkina Faso, the late 1980s and most of the 1990s were marked by a stagnation of the economy and a deterioration of the urban labor market (Diabré, 1998; Gaufryau, Maldonado, 2001). The economic crisis and the structural adjustment reforms implemented over this period, coupled with growing numbers of entrants into the urban labor market, particularly disadvantaged the new generation of jobseekers (Calvès, Schoumaker, 2004). Today, despite the economic upturn of the year 2000, un- 
employment and underemployment rates among young men and women are still disproportionately high in many African cities (SolignacLecomte, 2013; Roubaud, Torelli, 2013). In Ouagadougou, for instance, data collected among young adults in 2010 showed that about half of 20-year-old male respondents who had left school were out of the paid labor market at the time of the survey (Calvès, Kobiané, 2014). Although contemporary African youths are notably better educated than previous generations, they also have access to significantly less stable and less profitable jobs. With the formal sector unable to generate sufficient employment to absorb this rapidly growing segment of the labor force, new generations of young Africans are largely turning to the less profitable informal sector for economic activity (Filmer, Fox, 2014). In Ouagadougou, despite evidence of emerging private formal sector opportunities, $67 \%$ of young men and $77 \%$ of young women aged $20-35$ years old obtained their first paid employment in the informal sector of the economy (Calvès, Kobiané, 2014). While the informal sector should not be systematically associated with the working poor, young people also tend to be over-represented in the lower-paying informal activities necessary for survival and poverty rates among working African youth are high (Anyanwu, 2013).

The worsening of job prospects and increasing economic hardship for youths in African cities have significantly affected other important aspects of their transition to adulthood, including transition to first marriage. Whereas marriage could be described as early and universal in sub-Saharan Africa, since the end of 1970s the region has been moving into a new phase marked by a consistent rise in the age of first marriage in most countries, especially in urban areas (Marcoux, Antoine, 2014; Hertrich, 2017). Even in West Africa, where early marriage is still the norm in rural areas, rapid transformations have been observed in cities, including a postponement of first marriage by up to seven years from one generation to the next in some countries (Antoine, 2006). This delay of first marriage is often viewed as a result of both prolonged schooling and of increasing unemployment and the rising share of unstable and low-paying jobs among young male urbanites (Antoine, 2006; Calvès, 2007). Although the impact of young men's characteristics on their transition to marriage in Africa has attracted little attention compared to women's, a growing number of studies have recently shown the determining effect of economic activity on union formation among younger cohorts of city dwellers, and illustrated the marginalization of unemployed men on the marriage market (Antoine, 2006; Bocquier, Khasakhala, 2009; Calvès, 2007; Pike, 2016). The rising cost of bridewealth and of wedding expenditures, and the fact that these costs are increas- 
ingly borne by the groom alone in several African countries including Burkina Faso, are believed to explain this critical role played by male employment in the contemporary delayed transition to first union (Mokomane, 2005; Attané, 2002; Masquelier, 2005).

With a growing number of young city-dwellers forced to live with their parents longer and to remain single because they feel they cannot afford to do otherwise, observers throughout Africa report high levels of bitterness and frustration among male youths who feel «stuck» in poverty and are unable to take the expected social steps toward adulthood of marriage and residential independence (Sommers, 2012; Mains, 2012; Attané, 2002; Mazzocchetti, 2010). In a context where becoming a household head who provides for his family remains a keystone of masculinity construction, failure to do is perceived as a form of «male disempowerment» (Silberschmidt, 2001) or of «failed masculinity» (Sommers, 2012). Studies have also suggested that the inability of men to fulfill their role as providers has exacerbated gender tensions within African urban households, leading sometimes to domestic violence, divorce or even suicide (Silberschmidt, 2001; Bertho, 2012; Adinkrah, 2012). Increasing gender tensions associated with failed masculinity are also visible outside marriage. As Hunter (2010, p. 190) points out, «with the postponement of marriage, men have moved from being 'providers within marriage' to less reliable and less esteemed 'providers outside marriage'». In fact, while marriage is postponed, youths in African cities, including Ouagadougou, do not wait for marriage to become sexually active and are often engaged in several premarital sexual relationships (Rossier et al., 2013; Mazzocchetti, 2010). Like in most parts of the world, in urban Africa virtually all these intimate relationships have an economic component and gifts exchange is an essential aspect of the courting process. These economic exchanges are a «tacitly understood obligation» perceived by young men as a «duty» and by young women as an «expression of love and commitment» (Poulin 2007, p. 2'391). In fact, the affective and material dimensions of male-female relationships are intimately linked and «love and money» or «finance and romance» are highly intertwined in intimate relationships among African youths (Mills, Sewakiryanga, 2005; Thomas, Cole, 2009; Hunter, 2010).

Over the years, however, persisting unemployment and the increasing difficulties of young men to materially support their girlfriends and/or to commit themselves to marriage have put mounting pressure on intimate relationships. Tensions in the relationships between unmarried males and females are even believed to be turning into what is referred in francophone cities as a genuine «guerre des sexes» (a «gender war») 
(Sévédé-Bardem, 1997; Castro, 2012). In fact, in a context where formal marriage remains an essential source of social status and of financial security for women, single young females in the cities of Burkina Faso are still very eager to marry (Sawadogo, 2016). Like in other cities, however, they find it difficult to find a «capable man» and frequently complain about the «unreliability» and the «lack of seriousness» of men (Hunter, 2010; Mazzocchetti, 2010; Castro, 2012). Young women accuse their male counterparts of looking for immediate sexual satisfaction and of having multiple girlfriends whom they often entice with the promise of marriage to obtain sexual favors from them, only to later acknowledge that they had no intention of marrying them (Meekers, Calvès, 1997; Hunter, 2010; Castro, 2012). Young women also increas-ingly complain that some young men abscond once they hear their girl-friend is pregnant and/or fail to assume the financial and social responsibilities associated with fatherhood (Mazzocchetti, 2007; Berthot, 2016).

In return, young men in African cities are also often critical of their female counterparts, whom they claim, «will only love boyfriends with money» (Hunter, 2010, p. 193). Although money and gifts exchanges within unmarried romantic relationships are expected in urban Africa, today young men recurrently accuse young women of being «too materialistic» and of choosing their boyfriends solely based on their ability to provide them with economic support or gifts (Thomas, Cole, 2009; Castro, 2012; Hunter, 2010; Broqua, Doquet, 2013). With the persistent economic crisis since the 1990s, the postponement of marriage, and the rising consumerism among young people, the material aspect of unmarried relationships has become all the more critical. Single women are reported to increasingly use sexual relationships, sometimes with multiple concurrent partners, to specifically obtain resources for satisfying basics needs and/or for achieving idealized levels of consumption (Luke, 2005; Cole, 2009; Hunt, 2010; Rossier et al., 2013; Castro, 2012; Kamndaya et al., 2016).

The growing importance of money in intimate relationships, coupled with persistent unemployment, seems to be associated with rising inequalities among young men with respect to their abilities to attract girlfriends in urban Africa. In fact, poor male urbanites are not only «marginalized from the productive economy [but] also face marginalization from the sexual economy» (Hunter, 2010, p. 1'967). As one unemployed young man interviewed by Mains (2012, p. 120) in urban Ethiopia stated: «without work, I must simply sit with my desire». In a context where having both occasional and steady sexual partners, is a way for male ado-lescents and young adults to gain social status and show virility 
(Brown et al., 2005; Broqua, Doquet, 2013), this marginalization on the dating scene is also believed to generate considerable frustration and bitterness among unemployed and poorer youths (Mills, Sewakiryanga, 2005; Mazzocchetti, 2010; Mains, 2012; Sommers, 2012).

\section{Data and Methods}

The study uses data from a unique retrospective survey entitled «Becoming parents in Ouagadougou» (BPO survey) conducted in the capital city of Burkina Faso between November 2009 and February 2010. The survey was conducted among a representative sample of 2'036 young adults, of whom 1'109 were women and 927 were young men. To account for gender differentials in the patterns of transition to adulthood, female respondents targeted by the survey were slightly younger (20 to 29 years old) than their male counterparts ( 25 to 34 years old). Besides data on social origins (parents' occupation, religion, ethnic group) and complete retrospective residential, schooling, occupation and birth histories, the survey also collected a detailed history of the sexual relationships respondents have had during their life. While several life history calendar surveys have taken into account the complexity and diversity of matrimonial unions in Africa, the use of life history calendars to capture the dynamic processes of unmarried youths' romantic and sexual life histories is rare (Calvès et al., 2011; Luke et al. 2011). The survey goes beyond the typical matrimonial calendar (recording dates of traditional, religious, and/or civil matrimonial ceremonies) to collect information on marriage and cohabitation and all other significant sexual relationships, including the first relationship and all subsequent sexual relationships that lasted six months or more. For each relationship, several characteristics were collected including the date the relationship started, the date sexual activity was initiated, whether or not there were concurrent occasional sexual partners, whether or not the relationship ended up in a break-up, and if so, why. The dates of each of these events were also collected.

In addition to this detailed relationship history, information was collected on the social and economic origin of respondents, including their ethnicity, religion, and parents' occupation. Complete retrospective residential and activity histories were also collected. These histories contain several time-varying indicators of individual wealth: activity (in school, working, at home), level of educational attainment (no formal education, primary, secondary and post-secondary level of education) and 
«No money, no honey»?

Poverty and young men's unmarried relationships in urban Burkina Faso

type of employment performed (paid versus unpaid work, informal versus formal sector jobs) as well as living conditions (place of residence [Ouagadougou or other cities, rural areas, abroad] and housing wealth index for each residence).

The housing wealth index was constructed based on information collected on housing quality: house location (zoned versus spontaneous unzoned neighborhood), wall materials (cement/stone, mud brick or other), main source of drinking water (pipe into dwelling or other public outdoor tap, well, vendors, other) and lighting fuel (electricity, other). Thus, the BPO survey data provide a unique opportunity to analyze the effect of poverty on young men's ability to form «stable» sexual relationships (those lasting more than six months) over time and therefore test the «sexual marginalization» hypothesis (according to which poorer young men would face a disadvantage in meeting and keeping steady sexual partners compared to their better-off counterparts), using life history models.

The analysis is divided in two sections. The first section provides descriptive statistics on the relationship history of male respondents, including median age at first stable relationship, mean number of relationships reported and proportion of respondents who reported concurrent sexual partnerships. To investigate the effect of socioeconomic status on relationship history, a descriptive statistical analysis was performed using Kaplan-Meier methods. Differentials in the median time spent without a relationship are contrasted by four indicators of the socioeconomic status of respondents. The first two indicators pertain to the socioeconomic origin of male respondents. The occupation of the respondent's father (wage employment versus informal or agricultural sector work) and residence wealth index at 10 years old (low, medium and high) are included as fixed background characteristics. Besides economic origin, respondents' occupation and educational attainment were included in the models as individual time-varying measures of wealth and socioeconomic status. The variable measuring a respondent's main occupation is coded in four categories: inactive or performing unpaid work, in school, working in the informal sector and working the formal sector. The educational attainment variable includes four categories: no formal schooling, primary, secondary and post-secondary level of education. To further examine the impact of poverty on youth ability to enter into and stay in relationships, in the second section of the analysis we performed multivariate analysis using Cox conditional gap time models for repeated events (Cleves, 1999a; Box-Steffensmeier, Zorn, 2002). These models account for the fact that unmarried men move in and out 
of relationships and experience repeated «relationship spells». The analysis models the hazard of entering a relationship and focuses on unmarried adolescents and young men. Since we are interested in the transition to unmarried relationships, we constructed a survival data set where only spells during which respondents are single and without a relation-ship are at risk of the transition and consequently kept in the data file (Cleves, 1999b). We modeled the effects of young males' socioeconomic origins and time-varying occupational and educational status on the hazard of entering a relationship over time. In this model, only time spans when respondents are single and outside a relationship are considered. Thus, a respondent is under observation from childhood (age 10 years) until he enters a first relationship; he leaves the risk set during the time of the relationship and is observed again as soon as he experiences a breakup and becomes at risk of entering a second relationship, and so on. The 927 respondents generate a total of 4'262 person-month observations.

The four indicators of socioeconomic origin and status are included in the multivariate model as fixed (father's occupation and housing wealth index at age 10 years) and time-varying covariates (respondent's activity and educational attainment) to test the sexual marginalization hypothesis. Selected individual characteristics that are likely to affect the transition to a sexual relationship are integrated in the models as control variables. These variables include fixed background characteristics such as ethnic group affiliation (Mossi versus others) and religion (Christian versus non-Christian, including Muslim and Animist) and place of residence at 10 years of age and a time-varying covariate measuring age (10-14, 15-19, 20-24 and 25 and older).

If the sexual marginalization hypothesis is verified, we would expect poorer unmarried young men (those unemployed or performing unpaid work, and those men from disadvantaged socioeconomic background) to be less likely to form relationships compared to their counterparts with a paid job (especially those working in the formal sector of the economy) and those who grew up and lived in wealthier families. While educational attainment is not a direct measure of individual wealth it provides an indication of a young man's potential economic standing in the future. Thus, other things being equal, according to the sexual marginalization hypothesis, educational attainment should increase the hazard of finding a stable sexual partner, as educated young men should be perceived as more suitable future spouses and should therefore be more successful on the dating market than their uneducated counterparts. 


\section{Results}

\section{Relationship history and socioeconomic status: descriptive statistics}

Table 1 presents selected characteristics of relationship histories declared by male survey respondents.

TABLE 1 Selected characteristics of relationship history: male respondents aged 25-34

\begin{tabular}{|l|r|}
\hline $\begin{array}{l}\text { Median age at sexual initiation (years) } \\
\text { \% of respondents who ever had a stable sexual relationship at: }\end{array}$ & 21.4 \\
\hline Age 15 & 1.9 \\
\hline Age 19 & 18.0 \\
\hline Age 24 & 72.9 \\
\hline Age 29 & 94.0 \\
\hline $\begin{array}{l}\text { Median age at first stable sexual relationship (years) } \\
\text { Mean number of stable relationships declared }\end{array}$ \\
$\begin{array}{l}\text { \% of respondents who ever had overlapping stable relationships } \\
\text { \% of respondents who ever had an occasional sexual partner while in a stable rela- } \\
\text { tionship }\end{array}$ \\
\hline $\begin{array}{l}\text { \% of respondents who ever had concurrent stable or occasional sexual relationships } \\
\text { N= } 927\end{array}$ & 1.3 \\
\hline
\end{tabular}

Consistent with previous data on age at male sexual initiation in Burkina Faso (Welling et al., 2006) including the last DHS national survey, which reported a median age of 20.9 years in Ouagadougou, Table 1 shows that young men initiated their partnership history rather late, between age 21 and 22. By age 24, however, the large majority of them had already had a stable sexual partner. On average, men declared 1.3 stable relationships. Not all stable relationships were exclusive, however, and concurrent relationships, especially with occasional sexual partners, were frequent. In fact, the majority of men had ever had an occasional sexual partner while involved in a stable relationship (55\%) and some of them (11\%) reported overlapping stable relationships. Overall, the majority (56\%) of young men reported non-exclusive relationships.

Table 2 provides descriptive statistics based on Kaplan-Meier estimates of the median time spent by unmarried men without a relationship since age 10. 
TABLE 2 Median time spent by unmarried men outside stable sexual relationships since age 10 , by selected wealth indicators (in months)

\begin{tabular}{|c|c|}
\hline \multicolumn{2}{|l|}{ Socioeconomic background indicators } \\
\hline Father's occupation & $*(1)$ \\
\hline Informal/Agricultural work & 123 \\
\hline Employed in the formal sector & 113 \\
\hline Housing wealth index at 10 & $*$ \\
\hline Low & 124 \\
\hline Medium & 115 \\
\hline High & 118 \\
\hline \multicolumn{2}{|l|}{ Individual socioeconomic indicators } \\
\hline Activity & $* * *$ \\
\hline Unemployed/Performing unpaid work & 147 \\
\hline In school & 132 \\
\hline Employed in the informal sector & 26 \\
\hline Employed in the formal sector & 22 \\
\hline Educational attainment & $* * *$ \\
\hline No formal schooling & 134 \\
\hline Primary level & 140 \\
\hline Secondary & 32 \\
\hline Post-secondary & 20 \\
\hline All & 119 \\
\hline Person-months of observation & 4'263 \\
\hline
\end{tabular}

The median time spent outside a relationship is strongly and significantly associated with all four socioeconomic indicators. Differences by individual socioeconomic status are especially striking, and young men's occupation and educational attainment affect time spent outside relationships. In fact, young men who are unemployed or are performing unpaid work spent, on average, significantly more time without a steady sexual partner (147 months on average) compared to their employed counterparts (26 months and 22 months on average for those working in the informal sector and formal sector of the economy, respectively). Time spent outside relationships also declines with educational attainment, and post-primary education clearly seems to favor successful sexual partnership. Young men who never attended formal schools or only had a primary level education spent, respectively, 147 and 132 months without a partner, while those with secondary and post-secondary schooling spent 26 and 20 months respectively in that situation. Although differences by socioeconomic origin are less pronounced than they are by individual socioeconomic indicators, young men from poor- 
«No money, no honey»?

Poverty and young men's unmarried relationships in urban Burkina Faso

er family backgrounds (those whose fathers were employed in the agricultural or informal sector and those who grew up in poorer residences) experienced longer periods outside relationships compared to their counterparts from wealthier origins. For instance, young men who grew up in residences with a low wealth index at 10 years old spend on average 123 months outside a steady relationship, while those who spent their childhood in residences with a high economic index spend on average only 118 months in that situation.

\section{Effect of socioeconomic status on transition to unmarried relationships}

Table 3 presents the results of the conditional gap time Cox hazard analysis that models the effects of socioeconomic status on the hazard of engaging in relationships. To explore the mechanisms underlying this relationship, the effects of socioeconomic indicators are shown before (Model I) and after (Model II) controlling for fixed (ethnic group and religion, place of residence at age ten) and time-varying covariates (age).

As seen in Table 3, once individual-level socioeconomic indicators are controlled for, the positive effect of a respondent's more privileged social and economic origins on transition to an unmarried relationship is no longer statistically significant. This result suggests that young men from poorer economic backgrounds are disadvantaged on the dating market, largely because they have lower levels of education and less lucrative occupations over time than their counterparts from the wealthiest origins (those whose fathers had formal employment and those who come from richer residences). In fact, both individual timevarying socioeconomic indicators, namely occupation and educational level, have a clear and significant effect on young men's transition to unmarried stable relationships. The hazard of engaging in a relationship over time increases with educational level and is positively related to young men's working status, with employed men (especially those employed in the formal sector) being more likely to have steady sexual partners than unemployed men or young men performing unpaid work. 
TABLE 3 Transition to unmarried relationship:

Conditional gap time Cox model (hazard ratios)

\begin{tabular}{|c|c|c|c|}
\hline Socioeconomic background indicators & & Model I & Model II \\
\hline \multicolumn{4}{|l|}{ Father's occupation } \\
\hline (Informal/Agricultural work) & $\left(2^{\prime} 591\right)$ & & \\
\hline Employed in the formal sector & $1^{\prime} 671$ & 0.94 & 0.95 \\
\hline \multicolumn{4}{|l|}{ Housing wealth index at age 10} \\
\hline (Low) & $\left(1^{\prime} 775\right)$ & & \\
\hline Medium & 807 & 1.06 & 1.02 \\
\hline High & $1^{\prime} 680$ & 1.07 & 0.95 \\
\hline \multicolumn{4}{|l|}{ Individual socioeconomic indicators } \\
\hline \multicolumn{4}{|l|}{ Activity $^{\mathrm{tv}}$} \\
\hline (Unemployed/Performing unpaid work) & $(687)$ & & \\
\hline In school & $2^{\prime} 352$ & $1.36^{* *}$ & $1.32 *$ \\
\hline Employed in the informal sector & 928 & $1.67 * * *$ & $1.56 * * *$ \\
\hline Employed in the formal sector & 295 & $1.91 * * *$ & $1.78 * * *$ \\
\hline \multicolumn{4}{|l|}{ Educational attainment ${ }^{\mathrm{tv}}$} \\
\hline (No formal schooling ) & (640) & & \\
\hline Primary level & $1^{\prime} 459$ & 1.14 & 1.13 \\
\hline Secondary & $1^{\prime} 802$ & $1.37 * *$ & $1.29 *$ \\
\hline Post-secondary & 361 & $1.59 * *$ & $1.44 *$ \\
\hline \multicolumn{4}{|l|}{ Control variables } \\
\hline \multicolumn{4}{|l|}{ Place of residence at 10} \\
\hline (Ouagadougou/Other cities) & $\left(2^{\prime} 376\right)$ & & \\
\hline Rural areas & $1^{\prime} 349$ & & $0.81^{* *}$ \\
\hline Abroad & 537 & & 1.11 \\
\hline \multicolumn{4}{|l|}{$\operatorname{Age}^{\mathrm{tv}}$} \\
\hline (10 to 14 years old) & $\left(1^{\prime} 650\right)$ & & \\
\hline 15 to 19 years & $1^{\prime} 102$ & & 1.19 \\
\hline 20 to 24 years & $1^{\prime} 185$ & & $1.49^{* *}$ \\
\hline More than 25 years & 325 & & $1.85^{* *}$ \\
\hline \multicolumn{4}{|l|}{ Ethnic group } \\
\hline (Mossi) & $\left(2^{\prime} 880\right)$ & & \\
\hline Other & $1^{\prime} 382$ & & 0.94 \\
\hline \multicolumn{4}{|l|}{ Religion } \\
\hline (Muslim/animist) & $\left(2^{\prime} 003\right)$ & & \\
\hline Christian & $2^{\prime} 259$ & & 0.90 \\
\hline $\mathrm{N}$ & $4^{\prime} 262$ & 4263 & \\
\hline Prob > chi2 & & 0.000 & 0.000 \\
\hline
\end{tabular}

Source: 2010 BPO Survey.

As shown in Table 3, these positive effects remain significant in the full model (Model II), which includes important control covariates such as age, place of residence at age 10, ethnic affiliation and religion. Other 
things being equal, better-off respondents were still significantly more likely than their economically and educationally disadvantaged counterparts to be in a relationship over time. In fact, for unmarried males, paid employment was key to having stable sexual partnerships, and those working in the informal and formal sectors of the economy were respectively 1.6 and 1.8 times as likely as youths who were unemployed or engaged in unpaid jobs to be in relationships over time. Being in school is also an asset in the transition to an unmarried relationship. Providing further support for the sexual marginalization of socially disadvantaged youths, the multivariate analysis also confirms that, controlling for age and other covariates, the hazard of having a girlfriend significantly increases with educational attainment. As for the effect of control variables, as we could expect, the hazard of engaging in an unmarried relationship increases with age. While ethnic and religious affiliations have no significant effect on the hazard of getting a girlfriend, childhood place of residence does. Growing up in rural areas does not favor relationships formation (hazard ratios of 0.8 ).

\section{Discussion and Conclusions}

In a context where the expectation that a young man has to financially support his girlfriend is deeply rooted in social norms regarding gender roles (Lallemand, 1977), where masculinity construction is strongly associated with the ability to have girlfriends and multiple sexual partners (Mazzocchetti, 2010), but where the prolonged economic crisis has also severely affected youth employment (Calvès, Schoumaker, 2004), the purpose of the present research was to investigate quantitatively a phenomenon documented by anthropological research in urban subSaharan Africa: the increasing sexual marginalization of poorer young city-dwellers and their difficulties in finding and keeping sexual partners. To do so, we mobilized unique relationship history data collected from young adults in 2010 in Ouagadougou, the capital city of Burkina Faso. Important results emerge from the study. First, the data confirm that although unmarried young men in Ouagadougou have their first stable sexual partner rather late (around age 21), they do engage in a number of premarital relationships, either sequentially or simultaneously. Most respondents had occasional sexual partners while being in steady relationships, and some of them also had overlapping stable relationships. Unmarried young men are not equal in the search for stable sexual partners, however. Kaplan Meier descriptive statistics suggest 
that significantly longer periods of time are spent outside steady relationships by young men from poorer socioeconomic origins, uneducated youths, and those who are unemployed or performing unpaid work. Results from conditional gap time Cox models provide further support for the sexual marginalization hypothesis and show that, other things being equal, un-employed males and uneducated young men are significantly less likely to engage in relationships than their economically and socially better-off counterparts over time.

Thus, in a context where deteriorating economic conditions are believed to have exacerbated money-related conflicts and tensions between male and female youths in Burkina Faso (Sévédé-Bardem, 1997; Mazzocchetti, 2010), this study provides quantitative support for the growing sense among a number of young men that economic hardship restrains their sexual options. The difficulties faced by uneducated and unemployed young men in meeting and keeping stable sexual partners revealed by the analysis support the idea that inequalities among male youths in the productive economy are reflected in inequalities found in the sexual economy, and that social class is important in capturing modern masculinities in African cities (Hunter, 2010; Sommers, 2012; Broqua, Doquet, 2013). In fact, unemployed poorer youths are less able than their privileged counterparts to comply with the dominant model of masculinity since they cannot fulfill the social expectations of providing material support to their female partners. In Ouagadougou, where engaging in sexual relationships is a highly valued masculine trait (Mazzocchetti, 2010), the inability to have and keep steady sexual partners is likely to be associated with feelings of frustration and disempowerment.

Importantly, this marginalization on the dating market is also likely to affect the transition of poorer youths to marriage. In urban Burkina Faso, as in many other cities, unmarried young men engage in sexual relation-ships for love, to satisfy sexual and emotional needs but also to find a suitable spouse (Sawadogo, 2016). As in other African cities (Antoine, 2006; Bocquier, Khasakhala, 2009; Pike, 2016), previous research conducted in urban Burkina Faso actually showed that a later transition to marriage among the young generation of city-dwellers could be partly explained by the deterioration of their employment position (Calvès, 2007). Whereas for the earliest cohorts of men the timing of first marriage was not a matter of money, for the most recent generations, obtaining a paid job is crucial to the transition to first union. While the rising cost of bridewealth and marriage reported in many African countries (Mokomane, 2005; Lardoux, 2004; Masquelier, 2005) is likely to explain part of the growing importance of employment in access to mar- 
riage, the difficulties in engaging in unmarried steady relationships revealed by our study are also likely to play a role in the postponement of marriage observed among unemployed young men in urban Burkina Faso and in other African cities.

Nonetheless, this study has certain limitations. First, the analysis provides a partial picture of young men's sexual history since it only includes information on stable sexual relationships (those that lasted more than six months) and potential occasional sexual partners in the course of these relationships. Thus, some of the short-term sexual relationships the respondents may have had are not captured by the survey and the analysis could therefore not examine differentials in actual sexual celibacy of young men according to socioeconomic status. Second, because the relationship history did not include non-sexual partnerships, the research could not investigate the effect of poverty and social class on young men's ability to date girlfriends and engage in non-sexual courtship. Despite these limitations, however, the study provides strong statistical evidence of the disadvantage faced by uneducated and unemployed young men in meeting and keeping steady sexual partners compared to their counterparts with better socio-economic standing. Hence, the results confirm that the material aspect of unmarried relationships is critical is contemporary urban Africa and that gender expectations concerning male provision within these relationships is strong.

These findings have important practical implications. In a context of high rates of unwanted pregnancy, clandestine abortions, and sexually transmitted diseases (including HIV) among youth in Sub-saharan Afri$\mathrm{ca}$, projects and programs aimed at meeting the sexual and reproductive health (SRH) needs of adolescents and young adults have been increasingly common in the region over recent years. Since the 1994 International Conference on Population and Development in Cairo not only have young people become central targets of SRH initiatives but there is also a wide recognition of the need for the development of gendersensitive approaches, including interventions involving men and boys in reproductive health programming. In line with the conclusions from previous research (Barker, Ricardo, 2005; Dworkin et al. 2015), however, the results from our study suggest that the inequalities among young men and specifically the way poverty and social class intercept with male sexuality and masculinity need to be acknowledged when designing such interventions.

Lastly, these results suggest a number of avenues for future research. First, it would be interesting to investigate how these inequalities among men vis-à-vis unmarried relationships translate later in life, in 
terms of access to first marriage, but also to polygamy and to fatherhood, for instance. The potential impact of poorer men's inability to fulfill their provider role on the future of their union and on gender relationships within marriage would also deserve attention. Second, the effect of socioeconomic standing on the female position on the marriage market and young women's ability to enter unmarried relationships would be worth examining. While the expectation that a young man has to financially support his girlfriend is deeply rooted in social representations of men as providers, being employed and being educated may also be desirable attributes for a future wife in time of economic hardship and «failed masculinity».

\section{References}

Adinkrah M. (2012), «Better Dead than Dishonored: Masculinity and Male Suicidal Behavior in Contemporary Ghana», Social Science \& Medicine, 74 (4), pp. 474-481, https://doi.org/10.1016/j.socscimed.2010.10.011.

ANTOINE P. (2006), «Analyse biographique de la transformation des modèles matrimoniaux dans quatre capitales africaines: Antananarivo, Dakar, Lomé et Yaoundé», Cahiers Québecois de Démographie, 35 (2), pp.5-37, https://doi.org/10.7202/ 018591ar.

AnYanwu J. C. (2013), "Characteristics and Macroeconomic Determinants of Youth Employment in Africa», African Development Review, 25 (2), pp. 107-129, https:// doi.org/10.1111/j.1467-8268.2013.12019.x.

AtTANÉ A. (2002), «Identités plurielles des hommes mossi (Burkina Faso) : entre autonomie et précarité», Nouvelles Questions Féministes, 21 (3), pp. 14-27, https:// doi.org/10.3917/nqf.213.0014.

BARKer G., RICARdo C. (2005), Young Men and the Construction of Masculinity in Sub-Saharan Africa: Implications for HIV/AIDS, Conflict, and Violence, Washington DC, World Bank.

BeRtho B. (2012), «Trajectoires et revendications féminines dans le règlement des différends conjugaux autour de deux études de cas en milieu Mossi (Burkina Faso)», Autrepart, (2), pp. 99-115, https://doi.org/10.3917/autr.061.0099.

Bertho B. (2016), "'Le sang ne ment pas !' Conflits de paternité au Burkina Faso», Journal des Anthropologues, (1), pp. 169-189, https://doi.org/10.4000/jda.6409.

Bocquier P., Khasakhala A. (2009), «Factors Influencing Union Formation in Nairobi, Kenya», Journal of Biosocial Science, 41 (4), pp. 433-455, https://doi.org/10.1017/ s0021932009003319. 
BOX-STeffensmeier J., ZORN C. (2002), «Duration Models for Repeated Events», The Journal of Politic, 64 (4). pp. 1'069-1'094.

Brilleau A., Roubaud F., Torelu C. (2005), "L'emploi, le chômage et les conditions d'activité : enquête 1-2-3 phase 1», Statéco, 99, pp. 41-62.

Broqua C., Doquet A. (2013), "Les normes dominantes de la masculinité contre la domination masculine ? Batailles conjugales au Mali», Cahiers d'Études Africaines, 1 (209-210), pp. 293-321, https://doi.org/10.4000/etudesafricaines.17339.

Brown J., SORRell J., Raffaelu M. (2005), «An Exploratory Study of Constructions of Masculinity, Sexuality and HIV/AIDS in Namibia, Southern Africa», Culture, Health \& Sexuality, 7 (6), pp. 585-598, https://doi.org/10.1080/13691050500250198.

Calvès A. E. (2007), «Too Poor to Marry? Urban Employment Crisis and Men's First Entry into Union in Burkina Faso», Population, (English version), 62 (2), pp. 293 311, https://doi.org/10.3917/pope.702.0293.

CAlvès A. E., Kobiané J.-F. (2014), «Genre et nouvelles dynamiques d'insertion professionnelle chez les jeunes à Ouagadougou», Autrepart, (3), pp. 33-56, https://doi. org/10.3917/autr.071.0033.

CAlvès A. E., Kobiané J.-F., Thiombiano B., Loye A. (2011), «Devenir parent à Ouagadougou : l'expérience d'une enquête biographique originale en milieu urbain africain», Tremblay M. E., Lavallée P., El haj Tirari M. (eds), Pratiques et Méthodes de Sondages, Paris, Dunod, pp. 246-250.

Calvès A. E., Schoumaker B. (2004), «Deteriorating Economic Context and Changing Patterns of Youth Employment in Urban Burkina Faso: 1980-2000», World Development, 32 (8), pp. 1'341-1'354, https://doi.org/10.1016/j.worlddev.2004.03.002.

CAstro J. (2012), «Les filles sont trop matérialistes: tensions et soupçons dans les transactions sexuelles au Mali», D. FASSIN, J. S. EIDELIMAN (eds), Économies Morales Contemporaines, La Découverte, pp. 309-330.

CLeves M. (1999a), "Analysis of Multiple Failure-Time Survival Data», Stata Technical Bulletin, 49, pp. 30-39.

Cleves M. (1999b), "Stsetting Spell-Type Data», Stata Technical Bulletin, 49, pp. 3039.

Cole J., (2009), "Love, Money, and Economics of Intimacy in Tamatave, Madagascar», Cole J., Thomas L. M. (eds.), Love in Africa, Chapter 4, University of Chicago Press, pp. 109-134, https://doi.org/10.7208/chicago/9780226113555.003.0005.

DiAbré Z. (1998), "The Political Economy of Adjustment in Burkina Faso», Discussion Paper, 28, Caer II, Harvard Institute for Development, 137 p.

Dworkin S. L., Fleming P. J., Colvin C. J. (2015), «The Promises and Limitations of Gender-Transformative Health Programming with Men: Critical Reflections from the Field», Culture, Health \& Sexuality, 17 (sup. 2), pp. 128-143, https://doi.org/10. 1080/13691058.2015.1035751. 
Filmer D., Fox L. (2014), Youth Employment in Sub-Saharan Africa, World Bank Publications. 251 p.

Gaufryau B., Maldonado C. (2001), "Burkina Faso», B. Gaufryau, C. Maldonado (eds), L'économie informelle en Afrique francophone : structure, dynamiques et politiques, Geneva, International Labor Organization, pp. 147-183.

HeRTRICH V. (2017), "Trends in Age at Marriage and the Onset of Fertility Transition in sub-Saharan Africa», Population and Development Review, 43 (S1), pp. 112-137, https://doi.org/10.1111/padr.12043.

HUNTER M. (2010), Love in the Time of AIDS: Inequality, Gender, and Rights in South Africa, Indiana University Press, $303 \mathrm{p}$.

Kamndaya M., Vearey J., Thomas L., KabiRu C. W., Kazembe L. N. (2016), «The Role of Material Deprivation and Consumerism in the Decisions to Engage in Transactional Sex Among Young People in the Urban Slums of Blantyre, Malawi», Global Public Health, 11 (3), pp. 295-308, https://doi.org/10.1080/17441692.2015.1014393.

LaLLemand S. (1977), "Une famille Mossi», Recherches Voltaïques, 17, Ouagadougou, CVRS, Paris, CNRS.

LARDoux S. (2004), "Marital Changes and Fertility Differences of Women and Men in Urban and Rural Mali», African Population Studies, 19 (2), pp. 89-123.

LUKE N. (2005), "Confronting the 'Sugar Daddy' Stereotype: Age and Economic Asymmetries and Risky Sexual Behavior in Urban Kenya», International Family Planning Perspectives, 31 (1), pp. 6-14, https://doi.org/10.1363/3100605.

Mains D. (2012), "Young Men's Struggles for Adulthood in Urban Ethiopia: Unemployment, Masculinity, and Migration», V. AMIT, NOEL DYCK (eds), Young Men in Uncertain Times, pp. 111-132.

Masquelier A. (2005), "The Scorpion's Sting: Youth, Marriage and the Struggle for Social Maturity in Niger», Journal of the Royal Anthropological Institute, 11 (1), pp. 59-83, https://doi.org/10.1111/j.1467-9655.2005.00226.x.

Marcoux R., Antoine P. (2014), Le mariage en Afrique. Pluralité des formes et des modèles matrimoniaux, Québec, Presses de I'Université du Québec, https://doi. org/10.2307/j.ctt1f117sb.

MAzzocchettı J. (2007), «De l'autorité à l'affect : transformation des paternités au sein de la jeunesse ouagalaise scolarisée (Burkina Faso)», Recherches Sociologiques et Anthropologiques, 38 (2), pp. 47-64, https://doi.org/10.4000/rsa.459.

MAzzocchettI J. (2010), «À la recherche de l'homme capable... Concurrence entre femmes (Ouagadougou, Burkina Faso)", Civilisations, Revue Internationale d'Anthropologie et de Sciences Humaines, 59 (1), pp. 21-36, https://doi.org/10.4000/ civilisations.2241.

Meekers D., Calvès A. E. (1997), «Main Girlfriends, Girlfriends, Marriage, and Money: The Social Context of HIV Risk Behaviour in Sub-Saharan Africa», Health Transition Review, Supplément au volume 7, pp. 361-376. 
Mills D., SewakiRyanga R. (2005), "'No Romance Without Finance'. Commodities, Masculinities \& Relationships Amongst Kampalan Students», A. CoRnWALL (ed), Readings in Gender in Africa, Bloomington, Ind., Indiana University Press, pp. 90-95.

Mokomane Z. (2005), «Formation of Cohabiting Unions in Botswana: A Qualitative Study», Journal of Contemporary African Studies, 23 (2), pp. 193-214, https://doi. org/10.1080/02589000500176081.

PIKE I. (2016), «Economic Uncertainty and Marriage Timing for Rural and Urban Men in Malawi», Paper presented at the 42sd Quetelet Conference: Men's Perspective in Unions, Fertility and Parenthood, Louvain la Neuve, Belgium, November 910.

Poulın M. (2007), "Sex, Money, and Premarital Partnerships in Southern Malawi», Social Science and Medecine, 65, pp. 2'383-2'393, https://doi.org/10.1016/j. socscimed.2007.05.030.

Rossier C., SAwadogo N., Soubeiga A. (2013), «Sexualités prénuptiales, rapports de genre et grossesses non prévues à Ouagadougou», Population, 68 (1), pp. 97-122, https://doi.org/10.3917/popu.1301.0097.

Roubaud F., ToRelu C. (2013), «Employment, Unemployment, and Working Conditions in the Urban Labor Markets of Sub-Saharan Africa: Main Stylized Facts», Urban Labor Markets in Sub-Saharan Africa, Washington DC, World Bank, https:// doi.org/10.1596/9780821397817_ch01.

Sawadogo N. (2016), De l'initiation sexuelle au mariage chez les jeunes urbains burkinabè : relations, vécu et risques, Louvain-la-Neuve, Presses universitaires de Louvain, $380 \mathrm{p}$.

SÉvÉdé-BARDEM I. (1997), Précarités juvéniles en milieu urbain africain (Ouagadougou), Éditions L'Harmattan, Paris, 256 p.

SILBERSCHMIDT M. (2001), «Disempowerment of Men in Rural and Urban East Africa: Implications for Male Identity and Sexual Behavior», World Development, 29 (4), pp. 657-671, https://doi.org/10.1016/s0305-750x(00)00122-4.

SolignaC-LeComte H.-B. (2013), "L'Afrique est-elle vraiment bien partie ?», L'Économie Politique, 3 (59), pp. 49-60, https://doi.org/10.3917/leco.059.0049.

SOMMERs M. (2012), Stuck: Rwandan Youth and the Struggle for Adulthood, University of Georgia Press.

Thomas L. M., Cole J. (2009), "Thinking Through Love in Africa», J. Cole, L. M. THOMAs (eds), Love in Africa, University of Chicago Press, pp. 1-30, https://doi.org/ 10.7208/chicago/9780226113555.003.0001.

Weluings K. et al. (2006), "Sexual Behaviour in Context: A Global Perspective», The Lancet, 368.9548, pp. 1'706-1'728. 